\title{
PENGARUH PRAPERLAKUAN PREDNISON TERHADAP BIOAV AILABILITAS TEOFILIN PADA TIKUS WISTAR JANTAN
}

\author{
Dimas Adhi Pradana*, Farida Hayati, Elok Atiqoh \\ Farmasi Universitas Islam Indonesia \\ *email : adhi_pradana85@yahoo.com
}

\begin{abstract}
ABSTRAK
Penelitian ini bertujuan untuk mengetahui pengaruh pra-perlakuan prednison terhadap profil bioavailabilitas teofilin. Hewan coba yang dipergunakan dalam penelitian ini adalah tikus Wistar jantan yang dibagi dalam 2 kelompok yaitu kelompok kontrol dan perlakuan dimana setiap kelompok terdiri atas 5 ekor tikus. Kelompok kontrol diberikan teofilin dosis 45 $\mathrm{mg} / \mathrm{kg}$ BB tikus sedangkan kelompok perlakuan diberikan prednison dosis 3,6 $\mathrm{mg} / \mathrm{kg}$ BB tikus sekali sehari selama 7 hari dan pada hari ke-8 diberikan prednisolon. Cuplikan darah diambil sebanyak $0,25 \mathrm{ml}$ dari vena lateral ekor. Penetapan kadar fenitoin dilakukan dengan metode HPLC. Berdasarkan data kadar obat dalam darah lawan waktu dilakukan perhitungan parameter bioavalabilitas teofilin yang meliputi $\mathrm{Cp}_{\max }, \mathrm{t}_{\max }$ and $\mathrm{AUC}_{0-\infty}$. Hasil penelitian menunjukkan pemberian pra perlakuan prednison menurunkan secara signifikan nilai $t_{\max }$ dari teofilin sampai dengan $51,19 \%(p<0,05)$.
\end{abstract}

Keywords: farmakokinetika, prednison, teofilin

\section{ABSTRACT}

This research was aimed to find the effect of prednisone pre-treatment on theophylline bioavailability profile. This study followed a completely randomized design using male Wistar rats which divided into control and treatment groups each consisting of five test animals. The control group were given theophylline $45 \mathrm{mg} / \mathrm{kg}$ body weight of rat and the treated group were given prednisone $3,6 \mathrm{mg} / \mathrm{kg}$ body weight with a frequency of 1 times a day for 7 days before treated with theophylline. The serial blood samples were taken $0.25 \mathrm{ml}$ from the lateral tail vein for HPLC analysis of unchanged theophylline in blood. The concentration-time data of theophylline determines the theophylline bioavailability parameters i.e.
$\mathrm{Cp}_{\max }, \mathrm{t}_{\max }$ and $\mathrm{AUC}_{0-\infty}$.. The results indicated that prednisone pretreatment was found to decrease $t_{\max }$ of theophylline up to $51,19 \%$ $(p<0,05)$ but was not change the other theophylline pharmacokinetics significantly.

Keywords: Pharmacokinetics, prednisone, theophylline

\section{PENDAHULUAN}

Penggunaan teofilin bersamaan dengan obat lain sering kali dapat mempengaruhi klirens teofilin yang pada akhirnya dapat mempengaruhi efek terapi teofilin. Interaksi obat yang dapat memberikan dampak serius adalah jika terjadi penurunan klirens teofilin lebih dari $30 \%$ (Bauer, 2008). Beberapa contoh obat yang dapat menurunkan klirens teofilin adalah tiklopidin yang dapat menurunkan klirens teofilin sebesar $40 \%$. Contoh lainya adalah Allopurinol dosis tinggi ( $\geq 600$ $\mathrm{mg} /$ hari) dapat menurunkan klirens teofilin dengan signifikan dan simetidin dapat meningkatkan kadar serum teofilin akibat penghambatan metabolisme teofilin di hati. Kadar serum teofilin dapat meningkat signifikan akibat quinolon dan berpotensi menimbulkan toksisitas dengan signifikansi klinis tingkat dua (Tatro, 2009) (Aranson, 2005) (Stockley, 2010).

Kortikosteroid adalah obat antiinflamasi yang umum digunakan dan efektif untuk asma. Kortikosteroid sistemik oral digunakan untuk eksaserbasi pada asma persisten sedang dan berat sebagai 
tambahan pada bronkodilator untuk mempercepat pemulihan dan mencegah terulangnya eksaserbasi (Evidence $A$ ). Efek anti inflamasi yang efektif dari kortikosteroid diperoleh karena obat ini mampu memblokade reaksi alergi fase akhir, mengurangi hiperresponsivitas bronkus, dan menghambat aktivasi dan migrasi sel inflamasi (Dipiro et al, 2008). Penggunaan kombinasi teofilin-kortikosteroid pada terapi asma berpotensi menimbulkan interaksi obat terutama interaksi farmakokinetika. Oleh karena itu, penting dilakukan suatu penelitian untuk melihat adanya interaksi antara teofilin dengan obat golongan kortikosteroid yang salah satunya adalah Prednison. Untuk dapat melakukan skrining potensi interaksi pada semua fase farmakokinetik maka dipilihlah desain pemberian pra perlakuan Prednison selama 7 hari. Penelitian ini dilakukan untuk mengetahui pengaruh praperlakuan prednison terhadap profil bioavailabilitas teofilin dalam darah tikus putih jantan.

\section{METODE PENELITIAN}

Bahan yang dipergunakan dalam penelitian ini adalah prednison, teofilin murni standar farmasetis, asam trikloroasetat (TCA)10\%, buffer asetat (asam asetat glasial, natrium asetat dan aquabidest), asetonitril, heparin.

Alat yang dipergunakan adalah Gelas beker, gelas ukur, tabung reaksi, labu takar, pipet tetes, pipet ukur, pipet volume, propipet, mikropipet, batang pengaduk, spatula, neraca analitik, eppendrof, sentrifuge, spuit oral (ujung tumpul), stopwatch, seperangkat alat HPLC.
Hewan uji yang dipergunakan adalah tikus putih jantan galur Wistar umur 2-3 bulan dengan berat 200-300 gr.

\section{Penetapan kadar teofilin dalam darah}

Penetapan kadar teofilin dalam darah menggunakan HPLC mengikuti metode Wulandari (2011) dengan beberapa modifikasi dari peneliti. Modifikasi yang dilakukan berupa perubahan fase gerak, perbandingan TCA-darah, kecepatan dan lama waktu sentrifugasi, dan titik-titik pengambilan sampel. Darah sebanyak 0,25 $\mathrm{mL}$ ditampung di tube yang telah diberi 3-4 tetes heparin lalu dihomogenkan. Darah dipindahkan ke dalam tabung reaksi dan ditambahkan 0,25 $\mathrm{mL}$ asam trikloroasetat kadar $10 \%$, kemudian di-vortex dan disentrifuge selama 10 menit dengan kecepatan $2500 \mathrm{rpm}$ dan diambil beningannya sebanyak $240 \mu \mathrm{L}$ untuk dimasukkan dalam vial injektor dan diinjeksikan ke HPLC sebanyak $20 \mu \mathrm{L}$ secara autoinjeksi. Fase gerak yang digunakan adalah buffer asetat dan asetonitril (93:7) dengan laju alir $1 \mathrm{~mL} /$ menit dan panjang gelombang $271 \mathrm{~nm}$ (Wulandari, 2011).

\section{Uji pendahuluan}

a. Penetapan panjang gelombang serapan maksimum teofilin

Teofilin dilarutkan dalam fase gerak buffer asetat dan asetonitril (93:7) dengan kadar $4 \mu \mathrm{g} / \mathrm{mL}$ kemudian dibaca pada spektrofotometer UV-Vis pada batasan panjang gelombang 200-400 nm (Wulandari, 2011).

b. Penetapan waktu retensi dan selektivitas teofilin 
Teofilin murni dilarutkan dalam fase gerak hingga konsentrasi $20 \mu \mathrm{g} / \mathrm{mL}$. Hasil larutan dimasukkan dalam vial injektor, diambil secara autoinjeksi sebanyak $20 \mu \mathrm{l}$ ke dalam HPLC dengan menggunakan kolom C18, fase gerak buffer asetat dan asetonitril (93:7) pada laju alir $1 \mathrm{~mL} /$ menit dan panjang gelombang maksimum yang sudah didapat sebelumnya, kemudian ditetapkan waktu retensi dan selektivitas dari teofilin (Wulandari, 2011).

c. Penetapan kurva baku kadar teofilin dalam darah

Dibuat larutan stok teofilin $400 \mu \mathrm{g} / \mathrm{mL}$, $100 \mu \mathrm{g} / \mathrm{mL}, 50 \mu \mathrm{g} / \mathrm{mL}$ dan $10 \mu \mathrm{g} / \mathrm{mL}$ dalam aquabidest. Larutan stok 400 $\mu \mathrm{g} / \mathrm{mL}$ dibuat dengan cara menimbang $40 \mathrm{mg}$ teofilin murni kemudian dilarutkan dalam aquabidest sampai volume 100 $\mathrm{mL}$. Larutan stok $100 \mu \mathrm{g} / \mathrm{mL}, 50 \mu \mathrm{g} / \mathrm{mL}$ dan $10 \mu \mathrm{g} / \mathrm{mL}$ dibuat dengan cara pengenceran dari stok $400 \mu \mathrm{g} / \mathrm{mL}$.

Diambil sejumlah teofilin dari larutan stok kemudian ditambahkan dengan 0,25 $\mathrm{mL}$ darah dan ditambahkan TCA 10\% sejumlah 0,75 $\mathrm{mL}$. Seri kadar teofilin yang dibuat dalam darah adalah 0,$5 ; 0,8$; 1, 4, 6, 16, 20 dan $24 \mu \mathrm{g} / \mathrm{mL}$. Setelah itu, campuran di-vortex dan disentrifugasi selama 10 menit pada kecepatan 2500 rpm, dan diambil larutan beningnya. Larutan bening tersebut dimasukkan dalam vial injektor, diambil secara autoinjeksi sebanyak $20 \mu \mathrm{l}$ ke dalam HPLC dan diukur luas di bawah puncak kromatogramnya, kemudian dibuat regresi linier antara kadar terhadap luas di bawah puncak kromatogram teofilin (Wulandari, 2011).

d. Penetapan kriteria sensitivitas (LOD \& LOQ)
Batas deteksi (Limit of Detection/LOD) adalah konsentrasi analit terendah dalam sampel yang masih dapat dideteksi dan diidentifikasi dengan tingkat kepastian tertentu, tapi belum tentu dapat dikuantitasi.(Anonim, 2009). Batas kuantifikasi (Limit of Quantification/LOQ) adalah konsentrasi analit terendah dalam sampel yang dapat ditentukan dengan presisi dan akurasi yang dapat diterima pada kondisi operasional metode yang digunakan.Batas deteksi dan batas kuantifikasi dapat dihitung melalui persamaan regresi linier yang sudah didapat pada penetapan kurva baku.

e. Penetapan kriteria akurasi Kadar teofilin dalam darah dibuat dengan konsentrasi 4,6, 16, 20, dan $24 \mu \mathrm{g} / \mathrm{mL}$, kemudian diproses dengan menambahkan TCA $10 \%$. Setelah divortex dan di-sentrifuge selama 10 menit pada kecepatan 2500 rpm, beningan diambil dan diinjeksikan sebanyak $20 \mu \mathrm{l}$ pada HPLC, direplikasikan sebanyak 3 kali. Akurasi adalah kedekatan yang dapat diterima antara hasil sesungguhnya dan hasil aktual yang diperoleh. Akurasi biasanya dievaluasi dengan menentukan nilai recovery atau perolehan kembali (Ahuja, 2005) Perolehan kembali analit dalam pengujian merupakan suatu respon detektor yang diperoleh dari jumlah analit yang ditambahkan dan diekstraksi dari matriks, dibandingkan dengan respon detektor terhadap konsentrasi sebenarnya dari standar analit murni (Anonim, 2009). Perolehan kembali dari suatu pengujian tidak harus mencapai 
$100 \%$, tetapi tingkat perolehan kembali harus konsisten untuk semua kadar yang diujikan, presisi, dan reproducible, rentang penerimaan yang diperbolehkan untuk metode HPLC adalah 100 $\pm 15 \%$ (Anonim, 2009).

f. Penetapan kriteria presisi

Untuk mencari kesalahan acak, dari replikasi recovery sebanyak 3 kali dicari rata-ratanya sebagai nilai simpangan baku.

g. Penetapan stabilitas teofilin dalam pelarut TCA

Dibuat kadar teofilin $18 \mu \mathrm{g} / \mathrm{mL}$ dalam darah dan ditambahkan TCA 10\%, kemudian di-vortex dan disentrifugasi selama 10 menit pada kecepatan 2500 rpm, diambil larutan beningnya. Larutan bening disimpan dalam lemari pendingin selama 24, 48, dan 72 jam. Setelah itu, ditetapkan kadar teofilin dengan HPLC pada jam ke-0, 24, dan 48. Hasil yang diperoleh dinyatakan sebagai persen degradasi teofilin selama penyimpanan dalam pelarut TCA.

h. Penetapan dosis dan waktu sampling teofilin

Dosis teofilin awal yang digunakan dalam penelitian ini adalah $40 \mathrm{mg} / \mathrm{kg}$ BB (Wulandari, 2011). Setelah dilakukan optimasi waktu sampling diketahui bahwa pada dosis tersebut konsentrasi teofilin dalam darah pada jam ke 20 dan 24 berada di bawah nilai LLOQ, sehingga tidak memenuhi batas sensitivitas metode. Oleh karena itu, dilakukan peningkatan dosis menjadi $45 \mathrm{mg} / \mathrm{kg}$ BB tikus. Dosis Prednison yang dipergunakan sebesar 3,6 $\mathrm{mg} / \mathrm{kg}$ BB tikus yang merupakan hasil konversi dari dosis manusia. Jadwal waktu pengambilan sampel darah dicuplik dari vena lateralis ekor pada jam ke-0; 0,25; 0,5; 0,75; 1,0; 1,5; 2,0; 2,5; 3,0; 4,0; 6,0; 8,$0 ; 10,0 ; 12,0$, dan 24,0 (Wulandari, 2011)

i. Pengelompokkan hewan uji Hewan uji menggunakan tikus putih jantan galur Wistar, terdiri dari 2 kelompok, dipilih dengan mengikuti rancangan acak lengkap pola searah, dan tiap kelompok terdiri dari 5 ekor tikus, untuk kelompok I (kontrol) tikus diberikan rifampisin, sedangkan untuk kelompok II (perlakuan) diberi pra perlakuan prednison selama 7 hari, kemudian tersebut diberi perlakuan teofilin.

j. Uji Farmakokinetika

a. Kelompok kontrol

Sebanyak 5 ekor tikus putih jantan diberi teofilin secara oral dengan dosis $45 \mathrm{mg} / \mathrm{kg}$ BB. Pada jam ke-0, sebelum teofilin dipejankan, dilakukan pencuplikan darah tikus terlebih dahulu sebanyak 0,25 mL melalui vena lateralis ekor. Selanjutnya secara serial sampel darah dicuplik pada jam ke-0,5; 0,75; 1,0; 2,0;3,0; 4,0; 6,0; 8,0; 10,0; 12,$0 ; 15,0$ dan 24,0. Sampel yang telah diolah kemudian disimpan dalam lemari pendingin hingga dilakukan analisis kadar teofilin.

b. Kelompok perlakuan

Sebanyak 5 ekor tikus putih jantan diberi praperlakuan prednison dosis $3,6 \mathrm{mg} / \mathrm{kg}$ BB selama 7 hari kemudian diberi teofilin dosis $45 \mathrm{mg} / \mathrm{kg}$ BB dan secara oral. Pada jam ke0 , sebelum teofilin dipejankan, dilakukan pencuplikan darah tikus terlebih dahulu sebanyak $0,25 \mathrm{~mL}$ melalui vena lateralis ekor. Selanjutnya secara serial sampel darah dicuplik pada jam ke-0,5; 0,75; 1,0; 2,0; 3,0; 
4,$0 ; 6,0 ; 8,0 ; 10,0 ; 12,0 ; 15,0$ dan 24,0. Sampel yang telah diolah kemudian disimpan dalam lemari pendingin hingga dilakukan analisis kadar teofilin.

\section{HASIL DAN PEMBAHASAN}

Penetapan panjang gelombang serapan maksimum teofilin

Penetapan waktu retensi teofilin dan selektivitas metode

Selektivitas metode merupakan ukuran dari kemampuan dari suatu metode analisis untuk mengidentifikasi atau mengkuantifikasi analit dengan kehadiran komponen lain dalam matriks sampel, baik endogen atau eksogen. Untuk mengetahui selektivitas
Penetapan panjang gelombang maksimum (入maks) teofilin dalam fase gerak buffer asetat:asetonitril (93:7) menggunakan kadar $4 \mu \mathrm{g} / \mathrm{mL}$ dengan spektrofotometer UV-Vis. Hasil yang diperoleh menunjukkan bahwa serapan maksimum terdapat pada panjang gelombang $271 \mathrm{~nm}$.

metode yang digunakan dalam penelitian ini, maka dilakukan pengujian dengan membandingkan secara visual hasil kromatogram dari teofilin murni dalam fase gerak, blangko darah, dan teofilin dalam darah serta menghitung nilai koefisien selektivitasnya $(\alpha)$.

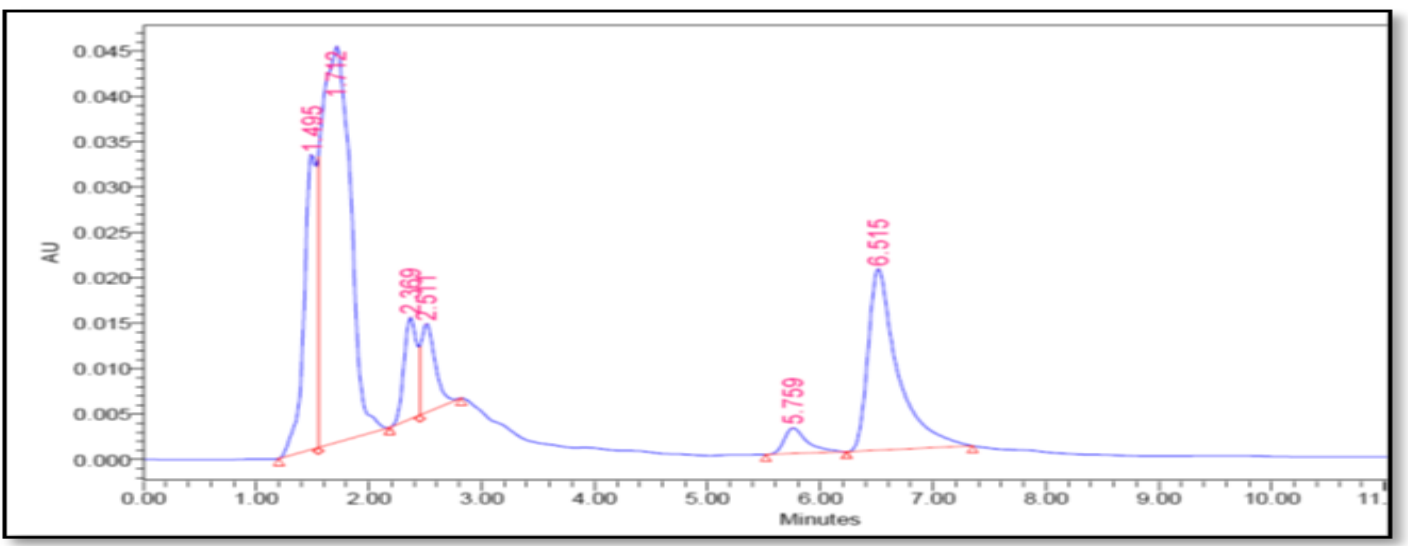

Gambar 1. Kromatogram HPLC teofilin kadar $20 \mu \mathrm{g} / \mathrm{mL}$ dalam darah tikus putih jantan Wistar dengan fase gerak buffer asetat:asetonitril (93:7) dengan kecepatan alir $1 \mathrm{~mL} /$ menit

Hasil penelitian menunjukkan bahwa nilai a sebesar 1,13 menunjukkan bahwa selektivitas metode yang digunakan dalam penelitian ini baik $(\alpha>1)$ (Ahuja \& Dong, 2005).

\section{Penetapan persamaan kurva baku teofilin dalam darah}

Penetapan persamaan kurva baku teofilin dalam darah bertujuan untuk mendapatkan suatu persamaan garis yang menghubungkan antara luas area dan kadar teofilin dalam darah. Prosedur ini dilakukan dengan membuat beberapa seri kadar teofilin dalam darah yang kemudian diukur luas area di bawah puncak kromatogramnya dengan menggunakan HPLC. Pada umumnya, metode dikatakan linear ketika hubungan antara respon metode dan konsentrasi analit dalam matriks berbanding lurus. Kriteria linearitas seringkali menggunakan koefisien korelasi (r). Suatu 
koefisien korelasi pada nilai 0,99 seringkali digunakan sebagai kriteria linieritas. Namun, nilai ini tidak mutlak, beberapa metode dengan nilai $r<0,99$ masih tetap dapat digunakan (Anonim, 2009)

Tabel 1. Pembacaan luas area di bawah puncak (AUC) kromatogram pada beberapa seri kadar teofilin dalam darah

\begin{tabular}{ccc}
\hline No & Seri kadar $(\mu \mathrm{g} / \mathrm{mL})$ & Luas area \\
\hline 1 & 1 & 14430 \\
2 & 4 & 59446 \\
3 & 6 & 92791 \\
4 & 16 & 255613 \\
5 & 20 & 329440 \\
6 & 24 & 388943 \\
\hline
\end{tabular}

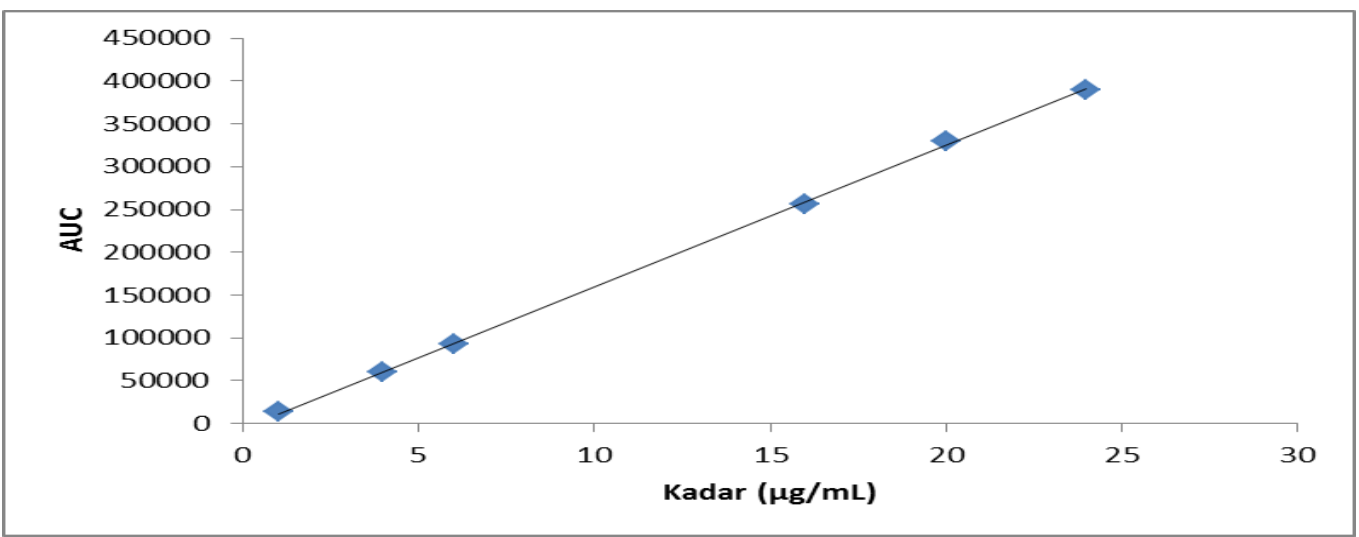

Gambar 2. Grafik kurva baku AUC vs kadar teofilin dalam darah tikus Wistar secara in vitro

Adapun persamaan kurva baku teofilin yang diperoleh adalah $\mathrm{y}=16515,81585 \mathrm{x}-$ 5665,56072 ; dengan $r=0,999$, dimana $x$ adalah kadar teofilin dalam darah dan $y$ adalah luas area di bawah puncak kromatogram (AUC) dari teofilin hasil pengukuran dengan HPLC.

\section{Penetapan kriteria sensitivitas}

Metode yang digunakan untuk menganalisis obat dengan konsentrasi yang sangat kecil pada spesimen biologis haruslah memiliki sensitivitas dan selektivitas yang tinggi. Sensitivitas adalah perbedaan pada konsentrasi analit yang memberikan respon terhadap adanya sedikit perubahan dalam metode yang masih dapat dideteksi (Anonim, 2009). Parameter sensitivitas dilihat dari nilai LOD dan LOQ. Batas deteksi (Limit of Detection/LOD) adalah konsentrasi analit terendah dalam sampel yang masih dapat dideteksi dan diidentifikasi dengan tingkat 
kepastian tertentu, tapi belum tentu dapat dikuantitasi (Anonim, 2009). Batas kuantifikasi (Limit of Quantification atau LOQ) adalah konsentrasi analit terendah dalam sampel yang dapat ditentukan dengan presisi dan akurasi yang dapat diterima pada kondisi operasional metode yang digunakan. Berdasarkan hasil perhitungan diperoleh nilai LOD dari metode yang digunakan dalam penelitian ini adalah $0,541 \mu \mathrm{g} / \mathrm{mL}$, nilai LLOQ sebesar $0,902 \mu \mathrm{g} / \mathrm{mL}$ dan nilai LOQ sebesar $1,804 \mu \mathrm{g} / \mathrm{mL}$.

\section{Penetapan kriteria akurasi dan presisi}

Akurasi adalah ukuran kedekatan hasil pengujian dan kadar sebenarnya. Presisi adalah ukuran kedekatan hasil analisis yang diperoleh dari serangkaian pengukuran dengan beberapa replikasi di bawah kondisi metode yang sama. Akurasi dan presisi bersama-sama menentukan total kesalahan analisis. Tolak ukur untuk kriteria akurasi adalah recovery (perolehan kembali), tolak ukur inakurasi adalah kesalahan sistematik, sedangkan kesalahan acak dan HORRAT (Horwitz Ratio) merupakan tolak ukur presisi dari metode analisis yang digunakan untuk penetapan kadar. Seri kadar teofilin dalam darah yang digunakan adalah 4, 6, 16, 20, dan $24 \mu \mathrm{g} / \mathrm{mL}$ dengan replikasi 3 kali. Tabel $\mathrm{V}$ menunjukkan nilai dari perolehan kembali, kesalahan sistematik, kesalahan acak, dan HORRAT dari metode penetapan kadar teofilin dalam darah pada penelitian ini.

Tabel 2. Nilai perolehan kembali, kesalahan sistematik, kesalahan acak, dan HORRAT pada penetapan kadar teofilin dalam darah tikus

\begin{tabular}{|c|c|c|c|c|c|}
\hline \multicolumn{2}{|c|}{ Kadar teofilin } & \multirow[b]{2}{*}{ Recovery (\%) } & \multirow[b]{2}{*}{$\begin{array}{c}\text { Kesalahan } \\
\text { Sistematik (\%) }\end{array}$} & \multirow[b]{2}{*}{$\begin{array}{c}\text { Kesalahan } \\
\text { Acak (\%) }\end{array}$} & \multirow[b]{2}{*}{ HORRAT } \\
\hline $\begin{array}{l}\text { Diketahui } \\
(\mu \mathrm{g} / \mathrm{mL})\end{array}$ & $\begin{array}{l}\text { Terukur } \\
(\mu \mathrm{g} / \mathrm{mL})\end{array}$ & & & & \\
\hline \multirow{3}{*}{4} & 4,002 & 100,041 & $-0,041$ & \multirow{4}{*}{0,639} & \multirow{4}{*}{0,098} \\
\hline & 4,020 & 100,491 & $-0,491$ & & \\
\hline & 3,969 & 99,232 & 0,768 & & \\
\hline \multirow{2}{*}{$\begin{array}{c}\text { Rata- } \\
\text { rata } \pm S D\end{array}$} & $3,997 \pm 0,026$ & $99,921 \pm 0,638$ & $0,079 \pm 0,638$ & & \\
\hline & 5,936 & 98,932 & 1,068 & \multirow{4}{*}{0,280} & \multirow{4}{*}{0,046} \\
\hline \multirow[t]{2}{*}{6} & 5,967 & 99,456 & 0,544 & & \\
\hline & 5,961 & 99,356 & 0,644 & & \\
\hline \multirow{2}{*}{$\begin{array}{l}\text { Rata- } \\
\text { rata } \pm S D\end{array}$} & $5,955 \pm 0,017$ & $99,248 \pm 0,278$ & $0,752 \pm 0,278$ & & \\
\hline & 16,119 & 100,746 & $-0,746$ & \multirow{4}{*}{1,105} & \multirow{4}{*}{0,210} \\
\hline \multirow[t]{2}{*}{16} & 15,790 & 98,684 & 1,316 & & \\
\hline & 15,849 & 99,055 & 0,945 & & \\
\hline \multirow[t]{2}{*}{$\begin{array}{l}\text { Rata- } \\
\text { rata } \pm S D\end{array}$} & $\begin{array}{c}15,919 \pm 0,17 \\
6\end{array}$ & $99,945 \pm 1,099$ & $0,505 \pm 1,099$ & & \\
\hline & 20,065 & 100,323 & $-0,323$ & \multirow{4}{*}{0,517} & \multirow{4}{*}{0,101} \\
\hline \multirow[t]{2}{*}{20} & 20,270 & 100,351 & $-1,351$ & & \\
\hline & 20,197 & 100,987 & $-0,987$ & & \\
\hline \multirow{2}{*}{$\begin{array}{l}\text { Rata- } \\
\text { rata } \pm S D\end{array}$} & $20,177 \pm 0,10$ & $100,887 \pm 0,52$ & $-0,887 \pm 0,521$ & & \\
\hline & $\begin{array}{c}4 \\
24,016\end{array}$ & $\begin{array}{c}1 \\
100,066\end{array}$ & $-0,066$ & \multirow{4}{*}{0,332} & \multirow{4}{*}{0,067} \\
\hline \multirow[t]{2}{*}{24} & 23,976 & 99,899 & 0,101 & & \\
\hline & 24,130 & 100,540 & $-0,540$ & & \\
\hline $\begin{array}{c}\text { Rata- } \\
\text { rata土SD }\end{array}$ & $\begin{array}{c}24,040 \pm 0,08 \\
0\end{array}$ & $\begin{array}{c}100,168 \pm 0,33 \\
3\end{array}$ & $-0,168 \pm 0,333$ & & \\
\hline
\end{tabular}


Data pada tabel 2 menunjukkan nilai rata-rata perolehan kembali maupun kesalahan acak dari masing-masing seri kadar masih termasuk dalam rentang nilai yang diperbolehkan untuk perolehan kembali $(100 \pm 15 \%)$ dan kesalahan acak (<15\%) pada metode HPLC (Anonim, 2009). Nilai HORRAT

yang berkisar antara 0,046-0,210 menunjukkan bahwa metode yang digunakan memiliki presisi yang baik, yaitu nilai HORRAT $<2$ (Anonim, 2011). Oleh karena itu, dapat disimpulkan bahwa metode analisis yang digunakan dalam penelitian ini memenuhi kriteria akurasi dan presisi.

\section{Penetapan stabilitas teofilin dalam pelarut TCA}

Stabilitas menunjukkan sejauh mana analit tetap stabil selama prosedur analisis keseluruhan, termasuk penyimpanan sebelum dan sesudah analisis (Anonim, 2009). Penetapan stabilitas teofilin dalam pelarut TCA dihitung sebagai persentase degradasi terhadap kadar awal ( $\mathrm{t}=0$ hari).

Tabel 3. Persentase degradasi teofilin dalam pelarut TCA pada penyimpanan dalam lemari pendingin

\begin{tabular}{cccc}
\hline $\begin{array}{c}\text { Hari } \\
\text { ke- }\end{array}$ & Luas Area & $\begin{array}{c}\text { Kadar Teofilin } \\
\text { dalam Darah } \\
(\mu \mathrm{g} / \mathrm{mL})\end{array}$ & $\begin{array}{c}\text { Degrada } \\
\text { si }(\%)\end{array}$ \\
\hline 0 & 291311 & 17,981 & 0 \\
1 & 263201 & 16,729 & 9,465 \\
2 & 257102 & 15,910 & 11,519 \\
\hline
\end{tabular}

Pemilihan waktu selama 3 hari dikarenakan sampel akan segera dianalisis kadarnya maksimal setelah 3 hari penyimpanan. Penelitian ini menggunakan waktu penyimpanan sampel dalam lemari pendingin selama 0,24, dan 48 jam kemudian ditetapkan kadar teofilin menggunakan HPLC dengan harapan kadar teofilin yang terdegradasi adalah sekecil mungkin.

\section{Penetapan dosis penelitian}

Pada awalnya dosis teofilin yang digunakan adalah $40 \mathrm{mg} / \mathrm{kg}$ BB tikus, tetapi kadarnya dalam darah pada jam ke 20 dan 24 saat optimasi waktu sampling berada di bawah nilai LOQ metode. Oleh karena itu, dosis teofilin dalam penelitian ini diubah menjadi $45 \mathrm{mg} / \mathrm{kg}$ BB agar kadarnya di dalam darah memenuhi kriteria sensitivitas metode. Dosis tersebut jika dikonversikan ke dalam dosis manusia masih berada dalam rentang yang diperbolehkan dalam sekali minum (500 mg) (Anonim, 2007). Sedangkan dosis prednison yang diberikan tiap harinya dalam penelitian ini adalah 3,6 $\mathrm{mg} / \mathrm{kg}$ BB (Dipiro et al, 2008).

\section{Penetapan waktu sampling}

Penetapan waktu sampling darah tikus dilakukan setelah pemberian teofilin dosis $45 \mathrm{mg} / \mathrm{kg}$ BB secara oral pada hewan uji. Waktu sampling yang digunakan adalah jam ke-0; 0,25; 0,5;0,75; 1,0; 1,5; 2,0; 3,0; 4,0; 6,0; 8,0; 10,0; 11,0; 20 dan 24,0 (Wulandari, 2011). 


\section{Penetapan model kompartemen}

Perhitungan parameter farmakokinetika selanjutnya mengikuti model kompartemen satu ekstravaskular.

\section{Hasil Penetapan Parameter}

\section{Farmakokinetika}

Data kadar lawan waktu teofilin yang diberikan secara oral pada kelompok kontrol dan perlakuan masing-masing disajikan pada tabel
IV. Perhitungan parameter farmakokinetika untuk masing-masing tikus pada kelompok kontrol dan perlakuan dapat diketahui pada tabel 4.

Tabel 4. Data kadar teofilin dalam darah $(\mu \mathrm{g} / \mathrm{mL})$ pada kelompok kontrol dan perlakuan $(n=5)$

\begin{tabular}{ccc}
\hline $\begin{array}{c}\text { Waktu Sampling } \\
\text { (jam ke-) }\end{array}$ & $\begin{array}{c}\text { Kelompok Kontrol (Rata- } \\
\text { rata } \pm \text { SE) }\end{array}$ & $\begin{array}{c}\text { Kelompok Perlakuan } \\
\text { (Rata-rata } \pm S E)\end{array}$ \\
\hline 0 & $0,00 \pm 0,00$ & $0,00 \pm 0,00$ \\
0,25 & $15,19 \pm 1,25$ & $12,43 \pm 0,71$ \\
0,5 & $17,31 \pm 1,02$ & $17,43 \pm 0,98$ \\
1,0 & $20,65 \pm 0,32$ & $26,13 \pm 2,09$ \\
2,0 & $24,22 \pm 0,36$ & $29,05 \pm 1,47$ \\
3,0 & $25,77 \pm 0,36$ & $27,19 \pm 2,09$ \\
4,0 & $28,61 \pm 0,30$ & $27,16 \pm 0,65$ \\
6,0 & $25,08 \pm 0,47$ & $21,73 \pm 1,09$ \\
8,0 & $22,54 \pm 0,44$ & $16,29 \pm 0,75$ \\
10,0 & $17,72 \pm 0,57$ & $11,00 \pm 0,78$ \\
12,0 & $15,41 \pm 0,57$ & $8,36 \pm 0,44$ \\
20,0 & $4,88 \pm 0,32$ & $1,74 \pm 0,37$ \\
24,0 & $2,43 \pm 0,14$ & $1,32 \pm 0,28$ \\
\hline
\end{tabular}

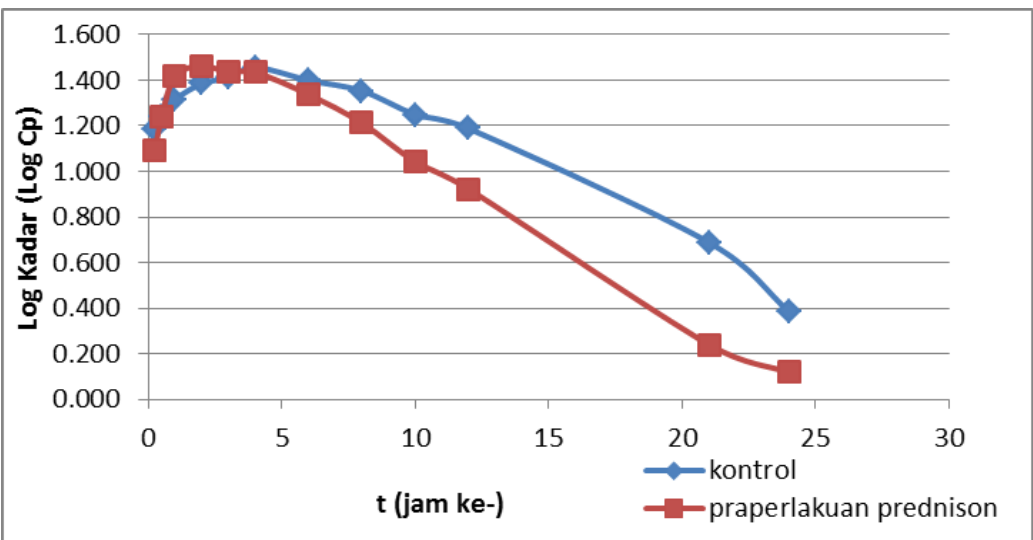

Gambar 3. Kurva kadar teofilin dalam darah tikus terhadap waktu pada kelompok kontrol dan praperlakuan prednison 
Tabel 5. Harga parameter farmakokinetika dan uji t tidak berpasangan untuk teofilin pada kelompok kontrol dan perlakuan

\begin{tabular}{|c|c|c|c|}
\hline \multirow{2}{*}{$\begin{array}{c}\text { Parameter } \\
\text { Farmakokinetika }\end{array}$} & \multicolumn{2}{|c|}{ Harga Parameter (Rata-rata \pm SE) } & \multirow{2}{*}{ \%Beda } \\
\hline & Kontrol & Perlakuan & \\
\hline$C p_{\text {maks }}(\mu \mathrm{g} / \mathrm{mL})$ & $24,428 \pm 2,013$ & $31,277 \pm 3,477$ & 28,037 \\
\hline$t_{\text {maks }}($ jam) & $4,706 \pm 0,238$ & $2,297 \pm 0,315^{*}$ & $-51,190$ \\
\hline $\mathrm{AUC}_{0-\infty}(\mu \mathrm{g} . \mathrm{jam} / \mathrm{mL})$ & $333,150 \pm 18,106$ & $285,361 \pm 19,680$ & $-14,345$ \\
\hline
\end{tabular}

Keterangan : * Memiliki perbedaan yang bermakna $(p<0,05)$ dibanding kelompok kontrol 


\section{Kadar maksimum dalam plasma ( $\left.C p_{\max }\right)$}

Konsentrasi plasma puncak menunjukkan konsentrasi obat maksimum dalam plasma setelah pemberian obat secara oral. Untuk beberapa obat, terdapat suatu

hubungan antara efek farmakologi dan konsentrasi obat dalam plasma. Cpmaks memberi suatu petunjuk bahwa obat cukup diabsorbsi secara sistemik untuk memberi suatu respon terapetik ataupun kemungkinan kadar toksik. Hal ini sangat berguna mengingat indeks terapi teofilin yang sempit. Nilai Cpmaks sangat dipengaruhi oleh laju absorpsi, laju eliminasi dan $t_{\text {maks. Hasil }}$ penelitian ini menunjukkan bahwa praperlakuan prednison dosis $3,6 \mathrm{mg} / 70 \mathrm{~kg}$ $\mathrm{BB}$ ternyata tidak mempengaruhi $\mathrm{Cp}_{\text {maks }}$ dari teofilin jika dibandingkan dengan kontrol, ditunjukkan dengan nilai probabilitas sebesar $0,127$ ( $p>0,05)$.

\section{Waktu saat obat mencapai kadar maksimum dalam plasma ( $t_{\text {maks }}$ )}

Waktu konsentrasi plasma mencapai puncak dapat disamakan dengan waktu yang diperlukan untuk mencapai konsentrasi obat maksimum setelah pemberian obat. Pada $t_{\text {maks, }}$ absorpsi obat adalah yang terbesar, artinya $t_{\text {maks }}$ merupakan parameter farmakokinetik di tahap absorbsi. Nilai $t_{\text {maks }}$ sangat dipengaruhi oleh laju absorpsi dan laju eliminasi obat. Absorbsi obat masih berjalan setelah $t_{\text {maks }}$ tercapai, tetapi pada laju yang lebih lambat. Harga tmaks menjadi lebih kecil (artinya lebih sedikit waktu yang diperlukan untuk mencapai konsentrasi plasma puncak) bila laju absorpsi obat lebih cepat (Shargel, 2005). Hasil penelitian ini menunjukkan bahwa praperlakuan prednison dosis 3,6 $\mathrm{mg} / \mathrm{kg}$ BB ternyata mempengaruhi $t_{\text {maks }}$ dari teofilin jika dibandingkan dengan kontrol secara signifikan, ditunjukkan dengan nilai probabilitas sebesar 0,000 ( $p>0,05)$.

\section{Area di bawah kurva (AUC)}

Area di bawah kurva konsentrasi obat-waktu (AUC) berguna sebagai ukuran dari jumlah total obat utuh yang tidak berubah yang mencapai sirkulasi sistemik dari $\mathrm{t}=0$ sampai $\mathrm{t}=\infty$. Nilai AUC bergantung pada jumlah total obat yang tersedia $\left(F D_{0}\right)$, tetapan laju eliminasi obat $(\mathrm{K})$, klirens total dan volume distribusi (Vd) (Shargel 2005) (Hakim 2011). Nilai AUC tidak bergantung pada rute pemberian dan proses eliminasi obat selama proses eliminasi obat tidak berubah. Satuan AUC adalah $\mu \mathrm{g}$ jam $/ \mathrm{mL}$. Untuk beberapa obat, nilai AUC berbanding langsung dengan dosis, jika dosis tunggal ditingkatkan menjadi empat kali lipat maka nilai AUC juga akan meningkat sebesar empat kali lipat (Shargel, 2005). Besarnya nilai $\mathrm{AUC}_{0-\infty}$ menggambarkan kadar obat dalam darah, artinya, nilai $\quad \mathrm{AUC}_{0-\infty}$ mempengaruhi intensitas aksi suatu obat. Intensitas aksi suatu obat bergantung pada jumlah total obat di tempat reseptor berada (Shargel, 2005). Jika jumlah total obat utuh dalam darah menurun, jumlah obat di reseptornya juga menurun, maka dapat terjadi penurunan efek farmakologi, begitu juga sebaliknya.

Hasil penelitian ini menunjukkan bahwa nilai $\mathrm{AUC}_{0-\infty}$ pada kelompok perlakuan lebih kecil dibanding kelompok kontrol. Hal tersebut menunjukkan bahwa praperlakuan prednison dosis 3,6 mg/kg BB menurunkan nilai $\mathrm{AUC}_{0-\infty}$ teofilin dibandingkan dengan kontrol, tetapi secara 
tidak signifikan, ditunjukkan dengan nilai probabilitas sebesar $0,016(p<0,05)$.

\section{KESIMPULAN}

Praperlakuan prednison dosis $3,6 \mathrm{mg} / \mathrm{kg}$ BB secara oral dengan frekuensi 1 kali sehari selama 7 hari pada tikus putih jantan galur Wistar dapat mempengaruhi $t_{\text {maks }}$ teofilin secara bermakna, yaitu mengalami penurunan sebesar $51,19 \%(p<0,05)$.

\section{DAFTAR PUSTAKA}

Ahuja, S., Dong, M.W., 2005, Handbook of Pharmaceutical Analysis by HPLC, Elsevier Inc., London

Arronson, J.K., 2005, Meyler's Side Effects of Drugs, Fifteenth Edition, Elsevier, United Kingdom, 3361-3370

Bauer, L.A., 2008, Applied Clinical Pharmacokinetics, Second Edition, The McGraw-Hill Companies Inc., New York

Dipiro, J.T., Talbert, R.L., Yee, G.C., Matzke, G.R., Wells, B.G., Posey, L.M., 2008, Pharmacotherapy A Pathophysiologic Approach, Seventh Edition, The McGraw-Hill Companies, Inc., USA

United Nations Publication, 2009 Guidance for the Validation of Analytical Methodology and Calibration of Equipment used for Testing of Illicit Drugs in Seized Materials and Biological Specimens, United Nations Publication, New York

Hakim, L., 2011, Farmakokinetik, Bursa IImu, Yogyakarta

Shargel, L., Pong, S.W., Yu, A.B.C., 2004, Applied Biopharmaceutics \& Pharmacokinetics, Fifth Edition, McGraw Hill's, New York 